\title{
Dennis Ocholla
}

\section{Marginalized Knowledge: An Agenda for Indigenous Knowledge Develop- ment and Integration with Other Forms of Knowledge}

\begin{abstract}
:
The purpose of this paper is to re-examine Indigenous Knowledge (IK) in order to suggest an agenda for its development and integration with other forms of knowledge. The paper discusses what marginalization of IK mean, examines the challenges of integrating IK in the mainstream of other forms of knowledges and suggests agenda for IK development. The suggested agenda focuses on mapping and auditing IK capacity in Africa, legal and ethical issues, IK management, IK education and training, integration of IK and KM, IK brain drain. The paper recommends that information on IK be widely shared for evaluation, use and further development.
\end{abstract}

\section{Agenda}

Introduction. 237

What does the marginalization of IK mean? 237

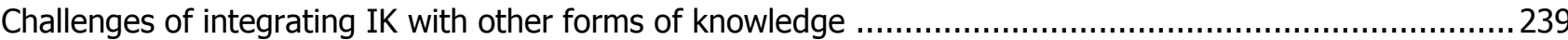

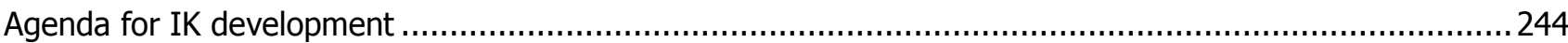

Conclusions

\section{Author:}

Prof. Dennis Ocholla:

- Department of Library and Information Science, University of Zululand

- $\bowtie$ docholla@pan.uzulu.ac.za 


\section{Introduction}

Present day's literature proffers several definitions of Indigenous Knowledge. The broadest of these (e.g. NRF, n.d.), which we intend to use, defines IK as a "complex set of knowledge and technologies existing and developed around specific conditions of populations and communities indigenous to a particular geographic area" with an emphasis on how "these forms of knowledge have hitherto been suppressed... therefore, IKS should be brought into the mainstream of knowledge in order to establish its place within the larger body of knowledge". Essentially, Indigenous Knowledge (i.e., lo$\mathrm{cal} /$ traditional/folk knowledge, ethno science) is a dynamic archive of the sum total of knowledge, skills and attitudes belonging to and practiced by a community over generations, and is expressed in the form of action, objects and sign language for sharing. Numerous examples ${ }^{1}$ (e.g Kaniki and Mphahlele 2002:4-6)) exist as to how IK thrives in beliefs, medicine ( traditional African medicine using herbs), community development (e.g. communality or the ubuntu support system), art and craft(e.g. pottery), sealing, energy production through charcoal burning), education (knowledge transfer through generations), communication and entertainment (festivals, drama, songs, dances, story telling/" what we could call today as "reading clubs", farming practices (soil conservation, intercropping, farm rotation), food technology (fermentation techniques, preservation), and arts and crafts (e.g. painting, curving, weaving, decoration). These skills, knowledge and attitudes, when shared, adapted and refined, sustain communities, and bring development in areas such as healing (e.g. alternative/traditional/herbal medicine, physical and mental fitness - acupuncture, yoga, tai-chi; Maasai's treatment of foot and mouth disease or Fulani treatment of cattle ticks with euphoria plants), nutrition (e.g. vegetarian cuisine, hoodia stem/cactus used by San people/clan to stave off hunger and control thirst/ "slimming drug" on hunting trips), wealth/income/business (e.g. intellectual property, tourism, informal sector or SMEs), education (e.g. customs, traditions, culture, language), entertainment (e.g. traditional music and dance), politics (conflict resolution through indaba, baraza, imbizo, kgotla etc.), architecture and design (housing - some wonderful African architecture exists in

${ }^{1}$ http://www.worldbank.org/afr/ik/basic.htm
Egypt and South Africa; clothes/attire), industry ( the informal sector) and countless more.

One of the focus area in Knowledge Management (KM) is the conversion of intangible knowledge (i.e. Indigenous Knowledge - IK) to tangible knowledge. Nonaka and Takeuchi (1995:62) define intangible knowledge as personal knowledge that is created through individual experiences. This knowledge is largely embedded within the culture and traditions of individuals or communities. Tangible knowledge, on the other hand, is recorded, documented or codified knowledge, widely conveyed through formal language, i.e. textual, electronic or digital. The manner in which this kind of knowledge is presented has made its storage, conveyance and sharing extremely easy and its popularization overwhelming. However, Nonaka and Takeuchi (1998:8) caution that tangible and intangible knowledge are not entirely two separate entities - they supplement each other. This is an area in which the integration of IK in mainstream knowledge, and more particularly in Knowledge Management, is inadequate. Knowledge, according to the two authors, is created and extended through the social interaction between tangible and intangible knowledge, and may follow four basic patterns:

- Intangible to intangible (socializing) - where individuals share intangible knowledge through personal contact.

- Intangible to tangible (externalization) where the knowledge base is extended by the codification of experience, insight and judgment so that it may be utilized by others.

- Tangible to tangible (combination) - where individuals combine the tangible knowledge of others to create a new whole.

- Tangible to intangible (internalization) where individuals use the codified knowledge of others to broaden their own intangible knowledge.

The purpose of this paper is to re-examine Indigenous Knowledge (IK) in order to suggest an agenda for its development and integration with other forms of knowledge.

\section{What does the marginalization of IK mean?}

Marginalization refers to exclusion - a state of being left out or insufficient attention to something for 
example IK.Although Indigenous Knowledge (which is still largely tacit or intangible) is inseparable from any realistic knowledge and Knowledge Management or classification paradigm, marginalization of IK has occurred over the years, and has retarded its development and integration. While IK has existed within our communities since time immemorial indeed, there is no community that does not have elements of IK - the degree of such possession varies, and seemingly the more a community possesses or practices it, the more the individual or community is marginalized or stigmatized. There are many speculative causes or reasons as to why this occurs. Of these, one stems from the characteristics of IK, i.e.: tacit knowledge is not codified or systematically recorded and therefore difficult to transfer or share; it lives solely in the memory of the beholder and is mostly oral, meaning that unless transferred, it dies with the beholder; it is embedded in the culture/ traditions/ideology/language and religion of a particular community and is therefore not universal and difficult to globalize; and it is mostly rural, commonly practiced among poor communities and is therefore not suitable in multicultural, urban and economically provided communities. The marginalization of IK can also be seen in light of how some global organizations, such as the World Bank and NUFFIC, associate IK with the poor. For example, in the World Bank website, "Indigenous knowledge is also the social capital of the poor, their main asset to invest in the struggle for survival, to produce food, to provide for shelter or to achieve control of their own lives"2.

Marginalization has also occurred because families and communities are becoming increasingly disintegrated and globalised, a trend that may have stemmed from the push and pull of technologies, and the over-extensive supply of mass products, services and mass media gadgets and content to private spaces where IK once thrived.

During periods of domination, which have been varyingly described with terms such as forced occupation, invasion, colonialism, servitude, apartheid, ethnic cleansing and imperialism; IK was subject to yet another level of marginalization. It was often referred to in a negative or derivative manner, with phrases such as primitive, backward, archaic, outdated, pagan and barbaric. This demeaning reference did not create space for IK's integration with other forms of knowledge, commonly referred to as scientific, western or modern knowledge (largely

\footnotetext{
${ }^{2}$ http://www.worldbank.org/afr/ik/basic.htm
}

products of explicit knowledge). Thus, if a community or a person recognized and utilized IK more, then that community or person was supposedly inferior to those that practiced the opposite. Put simply, a person or community practicing or using IK was stigmatized.

Therefore in order for an individual/community to be admitted into 'civilized' or modern society, that individual/community had to abandon practicing and using IK. IK was vindicated, illegitimated, illegalized, suppressed and abandoned by some communities, and the countries and peoples practicing it were condemned and associated with out datedness, a characteristic most people find demeaning. This form of marginalization produced a generation that for the most, does not understand, recognize, appreciate, value or use IK. Arguably, this situation has produced an intellectually "colonized" mindset. These are communities that the celebrated world novelist, Ngugi wa Thiongo, in his essay "Decolonizing the Mind: The Politics of Language in African Literature" consider to be intellectually colonized. The question is how much have they gained through losing? Or put another way, how much have they lost through gaining?

Marginalization has also been fuelled by stereotypes. There has been a tendency to associate IK with traditional communities. Studies on IK tend to focus on the poor, the developing countries, on the Aborigines of Australia, the Maoris of New Zealand, the Saskatchewan of Canada, the Red Indians of the United States, the Maasai of Kenya etc. The nature of these studies raises problematic questions, i.e.: Are the studies done to improve the welfare of the communities? Or are they done to demean such communities? Would such studies be done in order to gain and share knowledge on how well the communities solve problems using Indigenous Knowledge systems and methods? Are they done to unravel or demystify the stereotype paradigm? Alternatively, are such studies merely adventurous outlets justifying where research money has been spent? Would it not perhaps also be interesting to study the Indigenous Knowledge of western or industrialized communities? Whereas much can be gained from IK studies conducted on any community in the world (since each community contains elements of IK), the demeaning tendency to focus IK studies on traditional and poor communities has been an added cause to marginalization.

Ultimately, has marginalization occurred in the way we define IK in relation to broader knowledge or in the context of knowledge management? A worth 
challenging definition of knowledge in this context is that of Bells where, "knowledge is that which is objectively known, an intellectual property, attached to a name or a group of names and certified by copyright or some other form of social recognition [e.g publication]"(Bell, 1973:176). Bells definition of knowledge is a good example of modern or Eurocentric definitions of knowledge that can easily be used to marginalize/exclude Indigenous Knowledge, particularly if knowledge must be "attached to a name or a group of names and certified by copyright or some form of social recognition". This could be a biased approach that favors modern knowledge, recognizes explicit knowledge at the expense of tacit knowledge, and emphasizes codification and the ownership of knowledge that IK does not necessarily comply with

\section{Challenges of integrating IK with other forms of knowledge}

Fundamentally, integrating IK with other forms of knowledge first begins with knowledge creation and development processes that can be viewed in six steps, all of which are recognized by the World Bank (See Indigenous Knowledge for Development; a Framework for Action $\left(1998^{3}\right)$. The first step or process include recognition and identification, in that IK has to be recognized, identified and selected from a multitude of other knowledges. Step two involves IK's validation/affirmation by identifying its significance, relevance, reliability, functionality, effectiveness and transferability. This signifies an ability to support problem solving. For example, the HIV/Aids scourge, particularly in Africa, has invited a number of IK experimentations, most of which have not been validated (i.e. tested over time and used for problem solving) culminating in disasters in many cases. There are also interesting IK developments and practical achievements ${ }^{4}$ that are worth considering. Step three involves codification/recording / documentation. Explicit knowledge thrives because of its tangibility, sharability, transferability and storability etc., all of which originate from knowledge recordal system. Although there are some contestations to the recording of IK - the argument being that IK owners easily loose moral and material ownership of their intellectual property or capital, which is renegade to third parties - ex- plicit knowledge thrives because of its visibility, access and use. The fourth step consists of the storage of IK for retrieval. This requires the creation and development of IK repositories requiring taxonomies, databases, recording, indexing, and preservation for easy access and use. The IK database developed by the World Bank ${ }^{5}$ and those listed by Le Roux (2003) are essential examples. However, although IK databases are a brilliant idea, reliable content within the databases would be of greater value. For example, the World Bank database reflects only three records on South Africa, as indicated in Table 1, and 17 on Kenya (see Table 3).

3 http://www.worldbank.org/afr/ik/ikrept.pdf

${ }^{4}$ http://www.worldbank.org/afr/ik/iknotes.htm

${ }^{5}$ http://www.worldbannk.org/afrik/databases.htm 


\section{IK Database Search Results}

To view details click on practice title.

\section{Table 9 Indigenous Knowledge records search results in the World Bank database on South Africa (Source ${ }^{1}$ )}

\begin{tabular}{|c|c|c|c|c|}
\hline No. & Country & Domain & |Technology & Title \\
\hline 10 & Kenya & Agriculture & Agriculture & Botanical knowledge of the Maasai \\
\hline 41 & Kenya & $\begin{array}{l}\text { Health Nutrition } \\
\text { \& Population }\end{array}$ & $\begin{array}{l}\text { Traditional } \\
\text { Medicine }\end{array}$ & $\begin{array}{l}\text { Medicinal use of plants to alleviate } \\
\text { health problems of both human and } \\
\text { livestock. }\end{array}$ \\
\hline 42 & Kenya & Environment & $\begin{array}{l}\text { Biodiversity, } \\
\text { Conservation }\end{array}$ & $\begin{array}{l}\text { Taboos restrict felling of trees in the } \\
\text { Maasai steppe. }\end{array}$ \\
\hline 43 & Kenya & $\begin{array}{l}\text { Agriculture, } \\
\text { Environment }\end{array}$ & $\begin{array}{l}\text { Agricultural } \\
\text { Meteorology }\end{array}$ & $\begin{array}{l}\text { Weather forecasting on the basis of } \\
\text { astronomy and ecology. }\end{array}$ \\
\hline 44 & Kenya & $\begin{array}{l}\text { Agriculture, } \\
\text { Environment }\end{array}$ & $\begin{array}{l}\text { Biodiversity, } \\
\text { Taxonomy }\end{array}$ & $\begin{array}{l}\text { Use of plants and animals determines } \\
\text { their taxonomy. }\end{array}$ \\
\hline 46 & Kenya & Agriculture & Taxonomy & $\begin{array}{l}\text { Classification of livestock disease } \\
\text { names assists the Maasai in sharing } \\
\text { knowledge, diagnosing diseases and } \\
\text { preventing their impact. }\end{array}$ \\
\hline 47 & Kenya & $\begin{array}{l}\text { Health Nutrition } \\
\& \text { Population }\end{array}$ & $\begin{array}{l}\text { Knowledge } \\
\text { Management }\end{array}$ & $\begin{array}{l}\text { Sharing of medicinal knowledge } \\
\text { among the Maasai. }\end{array}$ \\
\hline 51 & $\begin{array}{l}\text { Eastern Africa } \\
\text { Region, Kenya }\end{array}$ & $\begin{array}{l}\text { Agriculture, } \\
\text { Health Nutrition } \\
\text { \& Population }\end{array}$ & Biodiversity & $\begin{array}{l}\text { Traditional societies in East Africa use } \\
\text { wild plants for different purposes and } \\
\text { means to survive. }\end{array}$ \\
\hline 58 & $\begin{array}{l}\text { Eastern Africa } \\
\text { Region, Kenya, } \\
\text { Tanzania }\end{array}$ & Edu & $\begin{array}{l}\text { Informal Edu- } \\
\text { cation }\end{array}$ & $\begin{array}{l}\text { Storytelling is the traditional means } \\
\text { to bridge past and present and to } \\
\text { transfer ethical values through the } \\
\text { generations. }\end{array}$ \\
\hline 63 & Kenya & $\begin{array}{l}\text { Health Nutrition } \\
\text { \& Population }\end{array}$ & $\begin{array}{l}\text { Traditional } \\
\text { Medicine }\end{array}$ & $\begin{array}{l}\text { Use of plants for their antibiotic } \\
\text { effects. }\end{array}$ \\
\hline
\end{tabular}

Item 445 has been a highly contested/controversial issue in South Africa's debate regarding IK intellectual property rights (see table 2 for illustration).

IK Practice Detail

${ }^{1}:$ http://www4.worldbank.org/afr/ikdb/ik results.cfm 
Practice title: A Landmark Agreement Recognizing the San's Intellectual Property Rights regarding their traditional knowledge of the Hoodia plant

Country: South Africa

$\begin{array}{llll}\text { Domain: } & \text { Health } & \text { Nutrition } & \text { \& }\end{array}$

Technology: Intellectual Property Rights

Bearers of Knowledge: The San peoples living in Angola, Botswana, Namibia, and South Africa

Summary: On March 24, 2003, after years of negotiations and uncertainty, representatives of the San peoples of southern Africa and representatives from South Africa's Council for Scientific and Industrial Research (CSIR) signed a benefit-sharing agreement for a drug being developed from a traditional mainstay of the San diet - the Hoodia plant. The Hoodia has been traditionally used by the San to treat stomach pain and eye infections, among other applications. On long hunting trips through the desert, San chewed on the stem of the Hoodia to suppress their hunger and thirst and boost their energy. In 1995, CSIR researchers discovered its qualities as an appetite suppressant, isolated the compound, called P57, in the plant that curbs hunger, and obtained a patent for it in 1996. The San pointed out that the Hoodia's distinctive properties were the exclusive traditional - and communal - knowledge of the San, passed down for centuries. Seeking acknowledgement of this fact, and of the collective ownership of this knowledge by the broader San community, they sued in 2000, which began a long process of negotiation with CSIR that only recently succeeded. The San stand to receive six percent of all royalties when the drug reaches the market. They plan to invest the money, and only tap into the interest generated to fund community projects. This benefit-sharing agreement between a local research council and the San people represents enormous potential for future collaboration, not only for the San but also for other holders of traditional knowledge.

\section{Lesson:}

Source: Cultural Survival Quarterly Issue 26.1, The Kalahari San: Self-Determination in the Desert, 2002.

Email:

URL: Cultural Survival

Table 10 Example of IK Intellectual Property Rights Agreement in South Africa. Source ${ }^{2}$ : Cultural Survival Quarterly Issue 26.1, The Kalahari San: Self-Determination in the Desert, 2002.

Examples from Kenya also draw significant interest largely because of the Maasais indigenous knowledge that has received minimal recognition.

\section{IK Database Search Results}

To view details click on practice title.

Your search returned 17 record(s).

${ }^{2}$ http://www4.worldbank.org/afr/ikdb/detail.cfm?id=445 


\begin{tabular}{|c|c|c|c|c|}
\hline No. & Country & Domain & Technology & Title \\
\hline 10 & Kenya & Agriculture & Agriculture & Botanical knowledge of the Maasai \\
\hline 41 & Kenya & $\begin{array}{l}\text { Health Nutrition } \\
\text { \& Population }\end{array}$ & $\begin{array}{l}\text { Traditional } \\
\text { Medicine }\end{array}$ & $\begin{array}{l}\text { Medicinal use of plants to alleviate } \\
\text { health problems of both human and } \\
\text { livestock. }\end{array}$ \\
\hline 42 & Kenya & Environment & $\begin{array}{l}\text { Biodiversity, } \\
\text { Conservation }\end{array}$ & $\begin{array}{l}\text { Taboos restrict felling of trees in the } \\
\text { Maasai steppe. }\end{array}$ \\
\hline 43 & Kenya & $\begin{array}{l}\text { Agriculture, } \\
\text { Environment }\end{array}$ & $\begin{array}{l}\text { Agricultural } \\
\text { Meteorology }\end{array}$ & $\begin{array}{l}\text { Weather forecasting on the basis of } \\
\text { astronomy and ecology. }\end{array}$ \\
\hline 44 & Kenya & $\begin{array}{l}\text { Agriculture, } \\
\text { Environment }\end{array}$ & $\begin{array}{l}\text { Biodiversity, } \\
\text { Taxonomy }\end{array}$ & $\begin{array}{l}\text { Use of plants and animals determines } \\
\text { their taxonomy. }\end{array}$ \\
\hline 46 & Kenya & Agriculture & Taxonomy & $\begin{array}{l}\text { Classification of livestock disease } \\
\text { names assists the Maasai in sharing } \\
\text { knowledge, diagnosing diseases and } \\
\text { preventing their impact. }\end{array}$ \\
\hline 47 & Kenya & $\begin{array}{l}\text { Health Nutrition } \\
\text { \& Population }\end{array}$ & $\begin{array}{l}\text { Knowledge } \\
\text { Management }\end{array}$ & $\begin{array}{l}\text { Sharing of medicinal knowledge } \\
\text { among the Maasai. }\end{array}$ \\
\hline 51 & $\begin{array}{l}\text { Eastern Africa } \\
\text { Region, Kenya }\end{array}$ & $\begin{array}{l}\text { Agriculture, } \\
\text { Health Nutrition } \\
\text { \& Population }\end{array}$ & Biodiv & $\begin{array}{l}\text { Traditional societies in East Africa use } \\
\text { wild plants for different purposes and } \\
\text { means to survive. }\end{array}$ \\
\hline 58 & $\begin{array}{l}\text { Eastern Africa } \\
\text { Region, Kenya, } \\
\text { Tanzania }\end{array}$ & Education & $\begin{array}{l}\text { Informal } \\
\text { cation }\end{array}$ & $\begin{array}{l}\text { Storytelling is the traditional means } \\
\text { to bridge past and present and to } \\
\text { transfer ethical values through the } \\
\text { generations. }\end{array}$ \\
\hline 63 & Kenya & $\begin{array}{l}\text { Health Nutrition } \\
\text { \& Population }\end{array}$ & $\begin{array}{l}\text { Traditional } \\
\text { Medicine }\end{array}$ & $\begin{array}{l}\text { Use of plants for their antibiotic } \\
\text { effects. }\end{array}$ \\
\hline
\end{tabular}

Table 11 Indigenous Knowledge records search results in the World Bank database on Kenya $\left(\mathrm{See}^{3}\right)$

${ }^{3}$ http://www4.worldbank.org/afr/ikdb/ik results.cfm 
Evidently, creating meta-data capturing capabilities and multiple storage approaches is becoming increasingly essential. Step five borders on IK transfer. Such transfers go beyond focusing on human recipients. Following this, step 6 , would be the dissemination and use of IK. Use of knowledge put it to testing, acceptance and further validation for development. Therefore in essence, the six steps or processes are essential if the gap between IK and other forms of knowledge is to be closed.

The second consideration for integration borders on pragmatism. Thus, what can we reap from IK. Other forms of knowledge have thrived because of their functions or importance or benefits. The recognition and development of IK is picking up momentum, largely due to the benefits being derived from it. For example, as already been mentioned, IK is increasingly being used for health services, particularly herbal/ traditional/alternative medicine and in agriculture, among others. Reported activities and practices of IK by the World Bank in "IK notes on Indigenous Knowledge"(2006'), which covers 93 documents from 1998 -largely focusing on Africa and Eastern and Southern Asia (e.g India and SriLanka) - shows ongoing activities and practices of tremendous achievement in the field of traditional medicine and health practices, agriculture, biodiversity, education, natural resource management, conflict management, energy generation and preservation etc; that are of great benefit to the communities in question. Additionally, business and trade through tourism has created significant interest in indigenous food, arts and craft (weaving, painting, sculpture and pottery). Significant growth has also been driven by pharmaceuticals. Unfortunately, most IK practices are currently being held in the informal sector/unregulated economy, and are therefore subject to abuse. It is acknowledged ${ }^{2}$ that IK provides skills, experiences and insights into individuals and communities which may, in turn, be used to improve the livelihoods of those mostly situated in the informal sector of the economy. Furthermore:

- " IK provides local communities - especially the poor - with problem solving strategies

- IK is an important contribution to global development knowledge

- IK systems risk extinction

${ }^{1}$ http://www.worldbank.org/afr/ik/iknotes.htm

${ }^{2}$ http://www.worldbank.org/afr/ik/basic.htm)
- IK is relevant for the development process

- IK is an under-utilized resource in the development process

Thus, learning from IK by investigating first what local communities know and have, can assist with understanding local conditions and provide a productive context for activities designed to help the communities $^{3}$

However, this document strongly views IK to be a survivalist instrument of development, meaning that its use is likely to occur less in areas where the lives of communities are better, or beyond the norm of survival. Will this be the case with pharmaceuticals or IK practitioners or even IK users, some of whom are not poor, and do not belong to the rural community? Put another way, how many people are employed in the IK industry who are not poor or come from the poor communities? Despite the rather sad denigration of IK, the World Bank recognizes that IK could be relevant in at least three levels of development, the first being that it is important in the local community in which the IK knowledge owners live and practice. Secondly, development agents such as NGOs, civil society, and governments, need to recognize, value, and appreciate it whilst integrating with local communities. Essentially, before incorporating IK into their approaches, they need to understand and critically validate it against the usefulness of their intended objectives. There are unique examples, such as South Africa's recent policy document on "Indigenous Knowledge Systems" 4 produced by the Department of Science and Technology, where government has integrated IK health workers, such as traditional healers, into mainstream national health care services by legislating a "Traditional Health Practitioners Legislation". This mandates the establishment of a "Traditional Health Practitioners Council to preside over the activities of approximately 200000 South African Traditional Healers". According to the refereed to document above, the "Traditional Medicine Strategy of World Health has noted that the use of traditional medicine is widely growing within Africa alone, as up to $80 \%$ of its population uses traditional medicine for their health needs,

${ }^{3}$ http://www.worldbank.org/afr/ik/why.htm 4

http://www.dst.gov.za/publications/reports/IKS P olicy\%20PDF.pdf 
largely due to accessibility and affordability". Thirdly, Indigenous Knowledge forms part of the Global Knowledge System. In this context, it has a value and relevance in and of itself. Thus, IK can be preserved, transferred, or adopted and adapted anywhere in the world. Some of the World Bank achievements as at 2005, in areas such as integrating IK in Bank projects [18 cases], mainstreaming IK in development [14 cases], building capacity to facilitate IK exchanges [22 cases], collection and dissemination of IK [12 cases] and building partnerships $[10 \text { cases }]^{5}$ are of great significance.

The third consideration is epistemological. The nature, origin, foundation, limitations and validity of IK requires further exploration and interrogation. For example Agrawal (2004), among others, identifies the key issues in a manner that poses the following questions: How does IK differ from scientific/modern/western knowledge? How do the two differ in dealing with immediate /concrete necessities as opposed to distant and abstract issues? What are the methodological and epistemological differences? And what are the contextual differences? It is therefore necessary to provide more epistemological content, concept and context to IK in order to broaden its understanding and application to research and education in Africa and wherever else there's such a need.

\section{Agenda for IK development}

- Mapping and auditing IK capacity in Africa (e.g. health, agriculture and food, trade and tourism). This may involve creating: an awareness of IK policies, legislations and strategies; management structures, programmes and activities; research output and recordable activities; centers and systems; support and funding; and knowledge holders and practitioners. This agenda appears to have been echoed also by Kaniki and Mphahlele (2002:14) as well as being given attention by the Department of Science and Technology ${ }^{6}$ of South Africa but not necessarily in other countries of Africa.

- Legal and ethical issues (e.g. policy, legislation, intellectual property rights). The issue

\footnotetext{
${ }^{5}$ http://www.worldbank.org/afr/ik/achieve.htm
}

6

http://www.dst.gov.za/publications/reports/IKS P olicy\%20PDF.pdf of the San people alluded to earlier is an example of why legal issues are important.

- IK management issues that borders on management structures within a country or institution, research, visibility-publication [see Ocholla and Onyancha 2006]), IK databases, creation of an IK website for its publicity and promotion [see Le Roux 20037 Jare equally valid issues.

- Education and training (e.g. workshops, seminars, conferences, short courses, IK knowledge fair, sharing of Best Practices, IK market place, popularization of IK, for instance in schools and in the curriculum of education institutions), which extends to the teaching of African history and literature (see African Writers Series- works written by Ngugi wa Thiongo, Chinua Achebe, Wole Soyinka, etc.) to students, thus bringing them closer to indigenous context.

- Integration of IK with KM. This should feature in KM research and teaching, curriculum development, publications, funding etc.

- IK brain drain. This first occurs in instances when an IK holder dies with knowledge that has not been widely shared through knowledge codification. Thus, when an IK holder dies, a whole community library disappears without trace. This type of brain drain is frequently ignored, yet quite important. Similarly, brain drain occurs in the form of migrated archives, where the IK of a community is displaced or transferred from its original location to a foreign location, thereby rending access and use difficult or impossible. The third instance occurs when a community's IK disappears due to the displacement or re-location of community members as a result of natural or artificial courses/disasters such as war, flooding, or urbanization.

\section{Conclusions}

The achievements made so far in the revival of Indigenous Knowledge, such as in South Africa and by the World Bank and other organizations, should be encouraged, supported and interrogated for further development within the country [SA] and in other parts of the world.

\footnotetext{
${ }^{7}$ http://www.worldbannk.org/afrik/databases.htm
} 


\section{Notes:}

A shortened version of this paper was presented at the African Information Ethics Conference on the 5$8^{\text {th }}$ February 2007 in Pretoria. The final version is to be published in the International Review of Information Ethics in 2007.

\section{References}

Agrawal, A. (2004) Indigenous and Scientific Knowledge: some critical comment. Indigenous Knowledge Monitor (3). [Online] : http://Www.nuffic.nl/ciran/ikdm/3-

3/articles/agrawal/html. Accessed 15 May 2007 from IK notes.

Bell, D. (1974) the coming of Post-Industrial Society: A venture in Social Forecasting, Basic Books, and New York

Indigenous Knowledge for Development. A Framework for Action (1998). [Online] http://www.worldbank.org/afr/ik/ikrept.pdf. Accessed 20 May 2007

Ngugi wa Thiongo (1986), Decolonizing the Mind: The Politics of Language in African Literature. Nairobi: Heinemann Kenya.

National Research Foundation (NRF). 2003. Indigenous knowledge systems. [Online]. Available WWW: $\quad$ http://Www.nrf.ac.zalfocusareas/iks/ Accessed 10 November 2005

Nonaka, I. \& Takeuchi, H. 1995. The knowledgecreating company: how Japanese companies create the dynamics of innovation. New York: Oxford University Press.

Kaniki, Andrew M. and Mphahlele, Kutu M.E. (2002) Indigenous knowledge for the benefit of all: can knowledge management principles be used effectively? South African Journal of Libraries and Information Science, 68(1), 1-14

Ocholla, D.N and Onyancha O. Bosire (2006) The marginalized knowledge. An informetric analysis of indigenous knowledge publications 19902004.South African Journal of Libraries and Information Science.Vol.71.No.3, 247-248

Le Roux, C.J.B. (2003), tapping indigenous knowledge on the world-wide web Indilinga African Journal of Indigenous Knowledge Systems, Vol 2, Issue 1, 107-113 